\title{
Economic Social Factor of Farmer and the Affect to Paddy Field Farming Productivity in Sungai Penuh City- Indonesian \\ DOI: https://doi.org/10.47175/rissj.v2i2.212
}

\author{
| Saidin Nainggolan ${ }^{1, *}$ | \\ 1,2,3 Deparment of Agribussines \\ Faculty of Agriculture Jambi \\ University \\ *saidinnainggolan64@mail.com
}

\begin{abstract}
Yanuar Fitri ${ }^{2}$ | Nur Fitri Ani ${ }^{3}$ |
ABSTRACT

The research aims to analyze economic social factor of farmer and the affect to paddy field farming productivity. Location determination do as purposive. Total of sample farmers are 62 farmers. Data analysis uses primary data and uses approach with Partial Least Square (PLS). Match test of outer model is convergent validity test, discriminant validity and composite validity are qualify. Inner model test has value of Q2 amount of 99,3\% meets match test of inner model. The affect of social factor and economic directly have coefficient amount of $-0,043$ and 0,038 to paddy field farming productivity with $p$ value $(0,046)<\alpha(0,05)$ and $p$ value $(0,033)<\alpha(0,05)$. The affect of social factor indirectly through of production input variable usage and activeness of farmer group have coefficients amount of 0,237 and 0,034 to productivity with $p$ value $(0,059)>\alpha(0,05)$ and $p$ value $(0,026)<\alpha(0,05)$. Economic factor through input production variable usage and activeness of farmer group have coefficients amount of 0,367 and 0,010 to productivity with $p$ value $(0,000)<\alpha(0,05)$ and $p$ value $(0,099)>\alpha(0,05)$. Total affect of the research of social factor and economic have coefficients amount of 0,228 and 0,415 to paddy field farming productivity with $p$ value $(0,064)>\alpha(0,05)$ and $p$ value $(0,000)<\alpha(0,05)$. The relation to this in order to empower farmer to raise of paddy field farming productivity need to pay attention of social factor, economic factor, cultivation technology of paddy field farming.

KEYWORDS

economic social; production input; activeness; productivity
\end{abstract}

\section{INTRODUCTION}

The result of Survei Pertanian Antar Sensus (2018) that the most higher sector who have total of household agriculture farming was food crop sector, especially paddy field amount of 13,15 millions households. Needs of food who increase to encourage people of agriculture to increase and develop of diversification food. Kementerian Pertanian (2018) proclaimed main target of agriculture development, is: self-sufficiency sustainability, increase food diversification, increase of value-added, competitiveness and export with increase of farmer welfare.

Jambi province has a potential to try paddy field farming and the result of production contributed for National in rank 17 from 34 province in 2018 (Kementan RI, 2019). Jambi province has some regions as center of production paddy filed. Sungai Penuh City as one of district who tried paddy field farming with land area harvest amount of 8.058 ha and production total amount of 48.387 ton with productivity amount of 6,00 ton/ha. In 20142017 paddy field farming at Sungai Penuh City have productivity increase amount of 3,36 $\%$ per year but have decrease of land area harvest and production amount of 10,02\% and $6,93 \%$ per year. 
The center production of paddy field in Sungai Penuh city is Sub-district Hamparan Rawang. Its contribute to Sungai Penuh city each other amount of 22,15\%. Paddy field farming productivity in Sungai Penuh city amount of 6,00 ton/ha. Progression of harvest area, production and productivity a long period of 2014-2017 have progress each other amount of 7,77 \%, 8,70 \% and 1,12\% per year. Soekartawi (2011) said that factors who affected to production differentiated to two classifications were biologic factor and economic social factor. Biologic factor (like agriculture land with assortment levels of fertility, seed, variety, fertilize, pesticide and others) and economic social factor (like production cost, price, labor, level of education, income and others).

The policy of paddy field farming need study about farmer economic social factor and affect of productivity. Age, farmer will me more easy in productive age and able to do farming program to increase productivity. The total member of family is how many member of family who can contribute in addition for labor in family to increase productivity of paddy field. High Education can increase skill of human resource and able to see the risk and will able to work as efficient for increase productivity. Experience of farming, the longer of experience in farming possible to farmer be able for increase paddy field farming. Land status may result in different of farming productivity. Source of livelihood, activity performed by human to cultivated of natural resource if main work as farmer, so more able to increase productivity. From this introduction, research aims to analyze economic social factor and the affect to paddy field farming productivity.

\section{RESEARCH METHODS}

This research did in April 2020 - October 2020. The sample region is Simpang Tiga Rawang village and Koto Dian village in Sub-district Hamparan Rawang Sungai Penuh City. The sample region did as purposive. The object of this research is paddy field farmer. Scope of this research is economic social factor of farmer and activeness in farmer's group towards paddy field farming productivity. The type of data was primary data obtained by used questionnaires. Sample size amount of 62 farmers determined by slovin method. Sample was carried out by incidental technique by non-probability approach, Sugiyono (2011) said that sampling incidentalnon probability was sample chosen by chance with researcher. Analysis toolwho used is Partial Least Square (PLS), doesn't require randomization. (Sarwono dan Narimawati, 2015) Model structural of this research can look at figure 1.

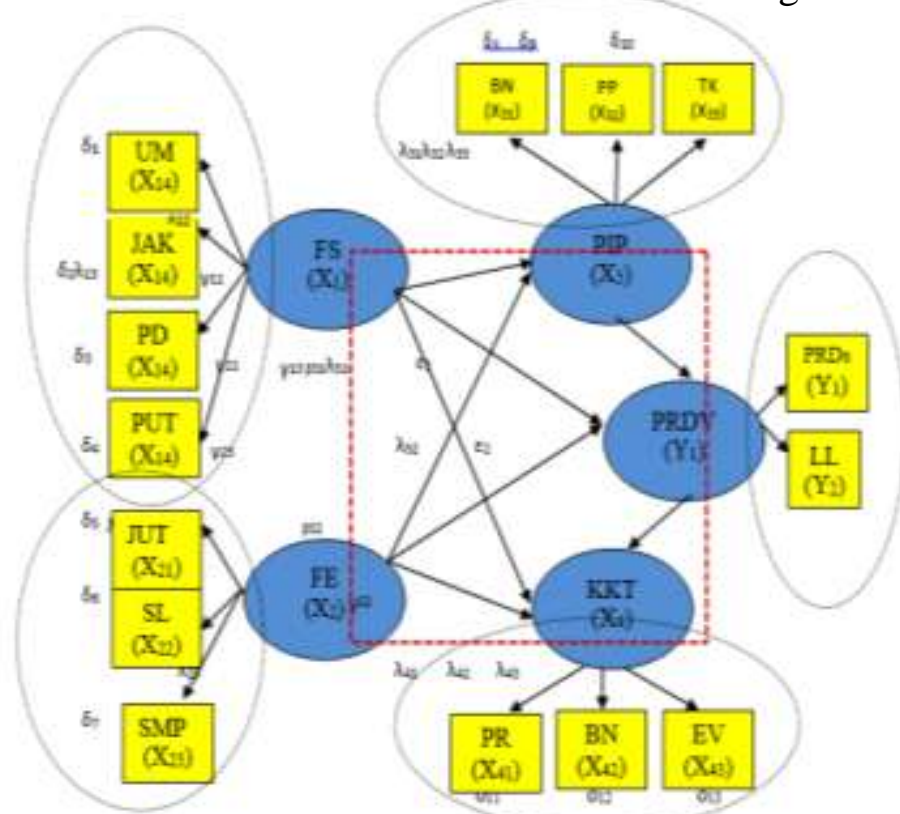

Figure 1. Path Diagram of The Effect Economic Social Factor to Paddy Field Farming 
Information:

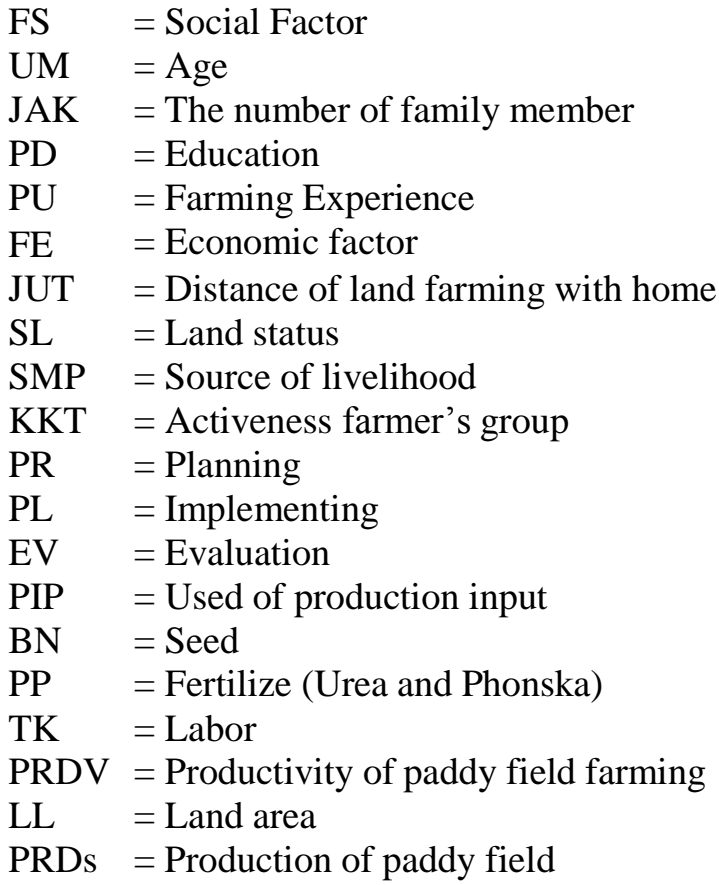

$\lambda($ Lamda kecil $)=$ Represent parameter related to the relation betweenexogenous latent variable $(\xi)$ and observed variable $(\mathrm{X}) /$ loading factor

$\delta($ Delta Kecil $)=$ Parameter related relation between residual variants fromobserved size $(\mathrm{X})$ or residual variants covariance from two observed sizes in exogenous side

$\varepsilon($ Efsilon kecil $)=$ Parameter related relation between residual variants fromobserved size $(\mathrm{Y})$ or residual variants covariance from two observed sizes in endogenous side

$\gamma($ Gamma kecil $)=$ Parameter related relation between exogenous variable $(\xi)$ and endogenous variable ( $\mathrm{n})$

$\beta$ (Beta Kecil) $=$ Parameter related relation between two endogenousvariable $(\eta)$

$\zeta$ (Zeta) $\quad=$ Covariance value between error (error) from $(\eta)$

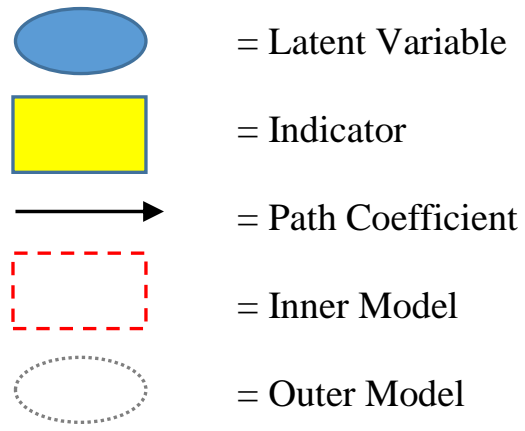

1. Goodness of Fit

a. Outer model (Convergent Validity, Discriminant Validity, and CompositeReliability)

b. Inner model (Goodness of Fit use value of $R$-Squared to count $Q$ Squared

was showed predictive relevance in path diagram of research). 


\section{RESULTS AND DISCUSSION}

\section{Measurement Goodness of Fit model}

Outer model showed how observed variable or manifest presented konstruk latent construction measured by Validity tested and latent construction reliability. The result of estimasiouter model is convergent validity, discriminant validity, dan compositevalidity can look at Table 1.

Table 1.Validity and Reliability of Farmer's Economic Social Factor and the Affected to Productivity of Paddy Field Farming in Region Research 2020

\begin{tabular}{|c|c|c|c|c|}
\hline \multirow[t]{2}{*}{ Instrument } & \multicolumn{2}{|c|}{ Validities } & \multicolumn{2}{|c|}{ Reliabilities } \\
\hline & $\begin{array}{l}\text { Factor } \\
\text { Loading }\end{array}$ & AVE & $\begin{array}{c}\text { Cronbach's } \\
\text { Alpha }\end{array}$ & $\begin{array}{c}\text { Composite } \\
\text { Reliability }\end{array}$ \\
\hline \multicolumn{5}{|l|}{ Social factor (X1) } \\
\hline - Age (X11) & 0,893 & & & \\
\hline - The number of family member(X12) & 0,817 & 0,672 & 0,390 & 0,771 \\
\hline - Education (X13) & $-0,561$ & & & \\
\hline - Farming Experience (X14) & 0,953 & & & \\
\hline \multicolumn{5}{|l|}{ Economic factor (X2) } \\
\hline - Distance of farming & 0,718 & & & \\
\hline - Land Status (X22) & 0,910 & 0,720 & 0,814 & 0,884 \\
\hline - Source of Livelihood (X23) & 0,904 & & & \\
\hline \multicolumn{5}{|l|}{ Input production used (X3) } \\
\hline - Seed $(X 31)$ & 0,991 & 0,961 & 0,979 & 0,987 \\
\hline - Fertilizer (X32) & 0,991 & & & \\
\hline - Labor (X33) & 0,957 & & & \\
\hline \multicolumn{5}{|l|}{ Activeness in farmer's group (X4) } \\
\hline - Planning (X41) & 0,983 & & & \\
\hline - Implementing (X42) & 0,978 & 0,950 & 0,974 & 0,983 \\
\hline - Evaluation (X43) & 0,963 & & & \\
\hline \multicolumn{5}{|l|}{ Productivity (Y) } \\
\hline - Land area (Y1) & 0,999 & 0,999 & 0,999 & 0,999 \\
\hline - Production (Y2) & 0,999 & & & \\
\hline
\end{tabular}

Table 1. showed that Convergent Validity relatively good. Value of outer loading, the value above 0,7 and AVE value dabove 0,5 . The thing means that each indicator is valid as estimator in latent variable except education variable. Discriminant Validity could see from the result of cross loading showed all of variables were social factor (X1), economic factor (X2), production input used (X3), activeness farmer's group (X4) and productivity of paddy field $(Y)$ of each indicator able to said that's good and valid

Latent variable (construct) in this research have good discriminant validity because its latent variable has strong correlation with every construct indicator except education variable. Composite Reliability Reliability test aimed to got research instrument with high accuracy looked from composite reliability value and cronbach's alpha. Some latent constructs estimated a variable have good reliability if it has composite reliability and cronbach's alphadiatas 0,7 (Hengky Latan, 2013). Cronbach's alpha value in social factor has a value under 0,7 but one of the other requisite is reliability composite has a value above 0,7 so fifth of model latent constructs were reliable in estimated research variables. 


\section{Evaluasi goodness of fit}

Evaluasi inner model can look from $R$-squared $\left(\mathrm{R}^{2}\right)$ to estimated the level of goodness of fit in structural model struktural and estimation test path coefficient to know about the affect of exogenous variable to variable endogenous.

Table 2. $\mathrm{R}^{2}$ Value Factor Social Variable and Economic to Paddy Field Farming Productivity in Reasearh Region 2020

\begin{tabular}{cc}
\hline & R Squared \\
\hline PIP & 0,238 \\
KKT & 0,488 \\
PRDV & 0,984 \\
\hline
\end{tabular}

Source: Data result from Smart PLS Versi 3.0, 2020

Table 2 showed that variable of used production input (PIP) have R2 value amount of 0,238, so model was in low category (Chin, 1998 in Sarwono and Narimawati, 2015). Activeness farmer's group variable (KKT) have R2 value amount of 0,488 , the meaning of that was Activeness farmer's group variable (KKT) could affected as together by social factor variable and economic factor amount of $48,8 \%$ so the category of model was moderat. Farming productivity variable (PRDV) have R2value amount of 0,984 this result showed that farming productivity variable (PRDV) could affected as together by social factor, economic factor, used of production input and activeness farmer's group amount of 98,5\% which mean model was strong/good category (Sarwono and Narimawati, 2015).

Q2 value of structural model described by inner model was amount of 0,9938 yaitu approached number of 1 so could said that structural model have suitability with good data (goodness of fit). Which mean that the information in data amount 99,3\% could described by structural model was social factor variable, economic factor, used of production input, activeness farmer's group and farming productivity.

\section{Direct Affect}

Table 3. Path Coefficient/ Direct Affect of Social Factor and Economic to Paddy Field Farming Productivity in Research Region 2020

\begin{tabular}{|c|c|c|c|c|c|c|}
\hline $\begin{array}{l}\text { Relation Between } \\
\text { Variables }\end{array}$ & $\begin{array}{l}\text { Path } \\
\text { Coefficient }\end{array}$ & $\begin{array}{l}\text { Sample } \\
\text { average }\end{array}$ & $\begin{array}{l}\text { Deviation } \\
\text { standard }\end{array}$ & $\begin{array}{c}\mathrm{t}- \\
\text { statistic }\end{array}$ & $\begin{array}{c}P \\
\text { Value }\end{array}$ & Information \\
\hline $\begin{array}{l}\text { Social factor }(\mathrm{X} 1) \text {-> } \\
\text { Used of production } \\
\text { input (X3) }\end{array}$ & 0,241 & 0,231 & 0,126 & 1,903 & 0,058 & $\begin{array}{l}\text { Positive and } \\
\text { non significant }\end{array}$ \\
\hline $\begin{array}{l}\text { Social factor (X1) -> } \\
\text { Activeness farmer's } \\
\text { group (X4) }\end{array}$ & 0,632 & 0,629 & 0,088 & 7,140 & 0,000 & $\begin{array}{l}\text { Positive and } \\
\text { very significant }\end{array}$ \\
\hline $\begin{array}{l}\text { Social Factor }(\mathrm{X} 1)-> \\
\text { Productivity }(\mathrm{Y})\end{array}$ & $-0,043$ & $-0,044$ & 0,021 & 2,000 & 0,046 & $\begin{array}{l}\text { Negative and } \\
\text { significant }\end{array}$ \\
\hline $\begin{array}{l}\text { Economic factor -> } \\
\text { used of production } \\
\text { input (X3) }\end{array}$ & 0,373 & 0,388 & 0,088 & 4,234 & 0,000 & $\begin{array}{l}\text { Positive and } \\
\text { significant }\end{array}$ \\
\hline $\begin{array}{l}\text { Economic factor (X2) } \\
->\text { activeness farmer's } \\
\text { group (X4) }\end{array}$ & 0,187 & 0,191 & 0,080 & 2,336 & 0,020 & $\begin{array}{l}\text { Positive and } \\
\text { significant }\end{array}$ \\
\hline $\begin{array}{l}\text { Economic factor }\left(\mathrm{X}_{2}\right) \\
->\text { Productivity }(\mathrm{Y})\end{array}$ & 0,038 & 0,037 & 0,018 & 2,141 & 0,033 & $\begin{array}{l}\text { Positive and } \\
\text { significant }\end{array}$ \\
\hline $\begin{array}{l}\text { Used of production } \\
\text { input (X3)-> } \\
\text { Productivity (Y) }\end{array}$ & 0,984 & 0,984 & 0,011 & 90,176 & 0,000 & $\begin{array}{l}\text { Positive and } \\
\text { significant }\end{array}$ \\
\hline
\end{tabular}




\begin{tabular}{lllllll}
\hline $\begin{array}{l}\text { Activeness farmer's } \\
\text { group (X4) } \rightarrow>\end{array}$ & 0,054 & 0,055 & 0,020 & 2,680 & 0,008 & $\begin{array}{l}\text { Positive and } \\
\text { significant }\end{array}$ \\
Productivity (Y) & & & & & &
\end{tabular}

Source: Data Result from Smart PLS Versi 3.0, 2020

Table 3 showed that social factor (X1) directly have positive affect and non significant ( $p$-value $=0,058>\alpha=0,050)$ to used of production input (X3) and have positive affect and significant to activeness farmer's group. (X4) more, have negative affect and significant to farming productivity (Y). Strengthening of social factor variable amount of $10 \%$ so will make increase of production input amount of $2,41 \%$, strengthening of activeness farmer's group amount of $6,32 \%$ and productivity amount of $0,43 \%$.

Economic factor has positive affect directly and significant to used of production input, activeness farmer's group and strengthening production of productivity amount of $10 \%$ so will make increase of input production used amount of 3,73\%, increase of activeness farmer's group amount of $1,87 \%$ and increase of farming productivity amountof $0,38 \%$. Used of production input has positive affect directly and significant to farmingproductivity. Strengthening of production input used amount of $10 \%$ so will makeincrease of farming productivity amount of 9,84\%. Activeness farmer's group has positive affect directly and significant. Strengthening of activeness farmer's group amount of $10 \%$ will make increase of farming productivity amount $0,54 \%$.

\section{Indirect Affect}

Table 4. Indirect affect of Social Factor and Farmer's Economic to Pengaruh Paddy Field Farming Productivity in Research Region 2020

\begin{tabular}{lccccc}
\hline $\begin{array}{c}\text { Relation between } \\
\text { Variable }\end{array}$ & $\begin{array}{c}\text { Original } \\
\text { Sample } \\
\text { (SO) }\end{array}$ & $\begin{array}{c}\text { Sample } \\
\text { Mean (M) }\end{array}$ & $\begin{array}{c}\text { Standard } \\
\text { Deviation } \\
\text { (STDEV) }\end{array}$ & $\begin{array}{c}\text { T- } \\
\text { Statistic }\end{array}$ & $\begin{array}{c}\text { P- } \\
\text { Value }\end{array}$ \\
\hline FS -> PIP -> PRDV & 0,237 & 0,228 & 0,125 & 1,896 & 0,059 \\
FS-> KKT-> PRDV & 0,034 & 0,035 & 0,015 & 2,229 & 0,026 \\
FE-> PIP -> PRDV & 0,367 & 0,382 & 0,086 & 4,287 & 0,000 \\
FE-> KKT -> PRDV & 0,010 & 0,011 & 0,006 & 1,654 & 0,099 \\
\hline \multicolumn{7}{c}{ Total of Indirect Affect } \\
\hline FS -> PRDV & 0,271 & 0,263 & 0,124 & 2,184 & 0,029 \\
FE -> PRDV & 0,377 & 0,392 & 0,085 & 4,432 & 0,000 \\
\hline
\end{tabular}

Source: Data Result from Smart PLS Versi 3.0, 2020

Table 4 showed that correlation coefficient of social factor through used of production input moderation to productivity have positive affect but non significant ( $\mathrm{p}$ - value $=0,059$ > $\alpha=0,050$ ) and by through activeness farmer's group moderation to farming productivity were positive affect and significant. Strengthening of social factor amount of $10 \%$ by used of production input moderation so will increase farming productivity amount of 2,37 \% and by activeness farmer's group moderation will increase farming productivity amount of 0,34 $\%$.

Economic factor through by used of production input moderation to farming productivity was positive affected and significant. Strengthening of economic factor amount of $10 \%$ by used of production input moderation will increase productivity amount of 3,67\%. The magnitude correlation coefficient economic factor throught by activeness farmer's group moderation to farming productivity was positive affected but no significant ( $\mathrm{p}$-value = $0,099>\alpha=0,050)$. Strengthening of economic factor amount of $10 \%$ by moderation variable will increase productivity amount of $0,10 \%$. 
Coefficient total affected indirectly of variable social factor to productivity was positive affected and significant. That could said indirectly every strengthening of social factor amount of $10 \%$ so will increase farming productivity amount of $2,71 \%$. Coefficient total affected indirectly economic factor to farming productivity was positive affected and significant. Strengthening of economic factor amount of $10 \%$ with moderation variable will increase farming productivity amount of 3,77 \%. The Result of Path Diagram of Farmer Social Factor and The Affect to Productivity can look at figure 2.

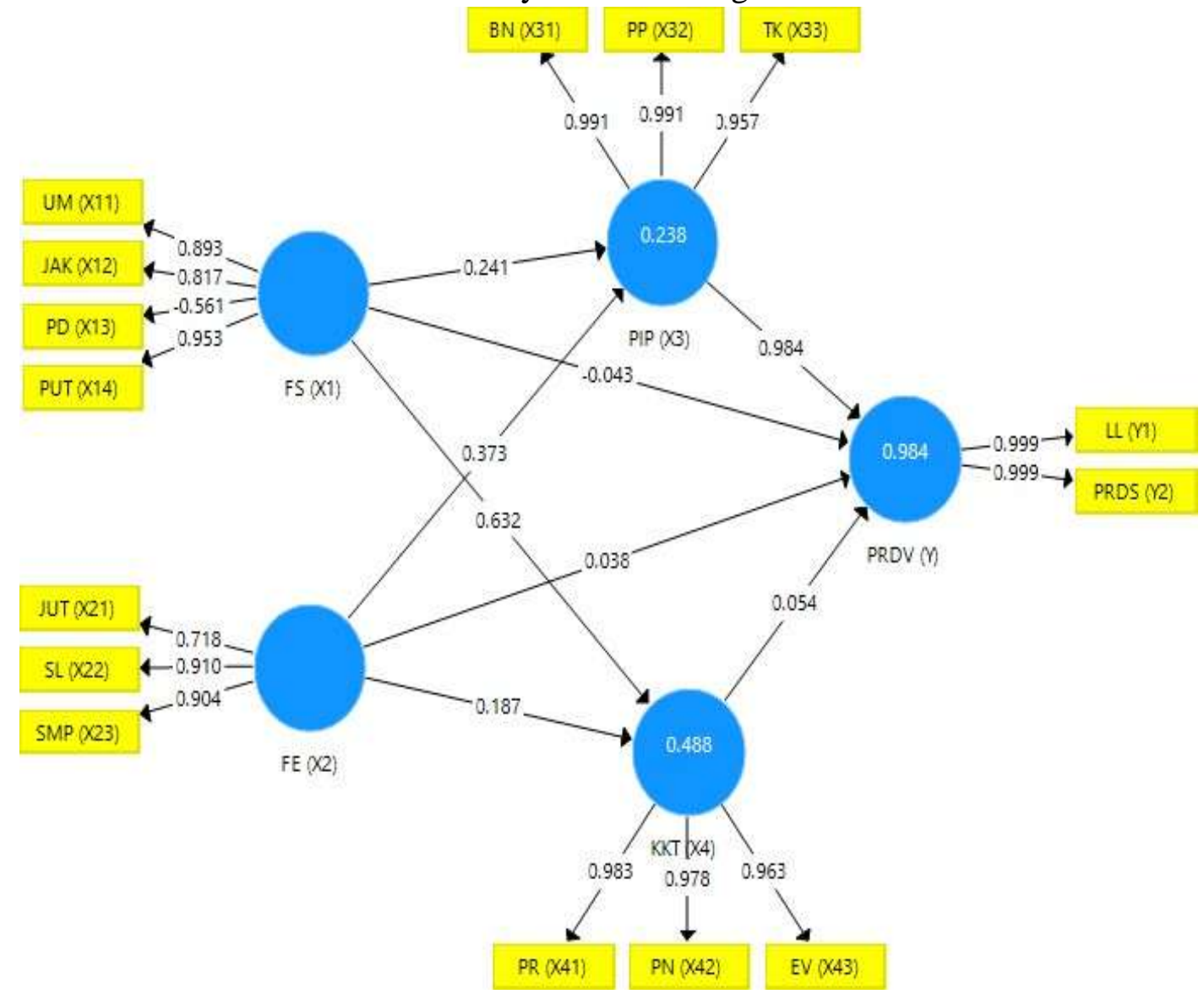

Figure 2. The Result of Diagram Path Structural Model Analysis

Image 2 showed that total affect was almost the same with affect directly. The different of it was in coefficient value relation between social factor to productivity and coefficient value economic factor to productivity. Social factor (X1) as total has positive affected but non significant ( $\mathrm{p}$-value $=0,058>\alpha=0,050$ ) to used of production input (X3), affected positive and significant to activeness farmer's group (X4) and affected positive but non significant $\mathrm{p}$-value $=0,064>\alpha=0,050)$ to farming productivity (Y). Strengthening of social factor as total amount of $10 \%$ will increase used of production input amount of $2,41 \%$, increase activeness farmer's group amount of $6,32 \%$ and increase productivity amount of $2,28 \%$.

Economic factor as total affected positive and significant to used of production input, activeness farmer's group and productivity. Strengthening of economic factor as total amount of $10 \%$ will make reveal used of production input amount of 3,73\%, reveal activeness farmer's group amount of $1,87 \%$ and reveal farming productivity amount of 4,15 $\%$. Total affect of production input used and activeness farmer's group to productivity affected positive and significant. So it could said that every reveal of used of production 
input and activeness farmer's group amount of $10 \%$ will reveal about productivity amount of $9,84 \%$ and $0,54 \%$.

The affect of social factor (age, the number of family member, education, and experience) its coefficient has positive value but non significant. Which mean getting older their age, the number of family member and farming experience as together through by social factor will increase productivity. Except, education who has negative value, where doesn't suitable as theory that said getting high education so can increase production of paddy field who as walk as with research by Hoar and Fallo (2017). Indicator of education affected positive to farming productivity, where education formal in research region was relatively high. According to Juita (2005) described that level of formal education unaffected to level of adoption technology PPT because for applied a technology in farming, farmer hasn't to have high level of formal education, not all of farmer have high education who have skill and more high knowledge than farmer who have low education. Research region assumed doesn't depend on formal education but from non formal education got from activeness farmer's group and their farming experience learned by hereditary or old family. The result of analysis social factor as walk as with research by Neobota and Kue (2016) farming experience variable affected positive but non significant. Research by Isyanto (2012) where said that age unaffected significant and have positive coefficient. The result of analysis economic factor as walk as with research by Sukayat and Rumna (2017) and Novita et al (2016) that land status variable affected significant.

The result of production input used as walk as with research by Bananiek, $\mathrm{S}$ and $\mathrm{Z}$ abidin (2013) Hasrani and Tangkesalu (2013) and penelitian Ifgayani et al, (2019) that seed variable, fertilizer and labor affected positive and significant. The affect of seed used, fertilizer, labor as together by used of production input in this research was more increase used of seed, fertilizer and labor will increase productivity. The result of analysis activeness farmer's group as walk as with research by Isma et al, (2018) and Bashir,MIA and Koestiono (2018) was any significant relation between role of farmer's group with paddy field productivity. Consistent stated by Mosher (1968) that one of condition smooth agriculture development was any farmer's activity joined in farmer's group. The affect of activeness farmer's group in this research was more active a farmer in activity (Planning, Implementing and evaluation) so will increase farming productivity.

\section{CONCLUSION}

The affect of social factor and economic directly have coefficient amount of $-0,043$ and 0,038 to paddy field farming productivity with $p$ value $(0,046)<\alpha(0,05)$ and $p$ value $(0,033)<\alpha$ $(0,05)$. Indirect affect of social factor through by used of production input and activeness farmer's group have coefficient amount of 0,237 and 0,034 to productivity with $p$ value $(0,059)>\alpha(0,05)$ and $p$ value $(0,026)<\alpha(0,05)$. Economic factor through by used of production input variable and activeness farmer's group have coefficient amount of 0,367 and 0,010 to productivity with $p$ value $(0,000)>\alpha(0,05)$ and $p$ value $(0,099)>\alpha(0,05)$. Total result affect of the research of social factor and economic have coefficient amount of 0,228 and 0,415 to paddy field farming productivity with $p$ value $(0,064))<\alpha(0,05)$ and $p$ value $(0,000)<\alpha(0,05)$. Related from this in order to improvement of paddy field farming productivity needs farmer empowerment with pay attention to social factor, economic factor, activeness farmer's group and effort from agriculture extension about new technology of paddy field farming. 


\section{REFERENCES}

Agus, Alamsyah. (2020). Practicing of Corporate Social Responsibility for Community Empowerment: A Case of a Mining Company in Indonesia. Randwick International of Social Science Journal, 1(3), 608-618. DOI:https://doi.org/10.47175/rissj.v1i3

Badan Pusat Statistik. (2019). The result of Agriculture Survey Between Census 2018 (SUTAS 2018). Accessed from https://www.bps.go.id/publication/2019/01/02/c7cb1c0a1db444e2cc726708/h asilsurvei-pertanian-antar-sensus--sutas--2018.html( on 20 September 2019)

Bananiek S and Z Abidin. (2013). Factor-factor of social economic affected to technology adoption of integrated crop management paddy field in Sulawesi Tenggara. Journal of assessment and development technology agriculture 16(2): 111-121. Agricultural Technology Research Center. Sulawesi Tenggara.

Bashir MIA and D Koestiono. (2018). Analysis of Social Economic Factor affected to farmer's decision in delay grain selling program in Dusun Krajan, Selodakon Village, Sub-district Tanggul, District Jember. Journal of Agriculture Economic and Agribusiness (JEPA) 2(3) : 204-210. Faculty of Agriculture UB. Malang.

Ghozali, Imam. (2014). Structural Equation Modeling Metode Alternatif with Partial Least Square. Edition 4. Diponegoro University. Semarang

Gunarto, Muji. (2018). Analysis Of Statistic With Sructural Equation Model (SEM): Teoritis $\&$ Praktis. Alfabeta. Bandung.

Hasrani NT and D Tangkesalu. (2013). Analysis Of Efficiency Used Of Production Input Paddy Field Farming In Poleganyara Village Sub-District Pamona Timur District Poso. J. Agroland 19(30): 200-206. Faculty of Agriculture Tadaluko University. Palu.

Hoar E and YM Fallo. (2017). The Affect Of Farmer Economic Social Factor To Corn Farming Production Badarai Village Sub-District Wewiku District Malaka. Journal of Agrimor 2(3): 36-38. Faculty of Agriculture UNIMOR. Kefamenanu, NTT.

Ifgayani, I M Antara, L Damayanti. (2019). Analysis of factors affected to paddy fiel production in Uetoli Village Sub-district Ampana Tete District Tojo Una-Una. Journal of agriculture science agroland 26(2): Faculty of Agriculture UNTAD. Palu, Sulawesi Tengah.

Latan, Hengky. (2012). Structural Equation Modeling Concept and Application use Lisrel

8.80 Program . Alfabeta. Bandung.

Sarwono J and U Narimawati. (2015). Make Essay, Thesis, and Dissertation with Partial Least Square SEM (PLS-SEM). ANDI. Yogyakarta.

Sukayat H and Rumna. (2017). Analysis of Income and Factors od Economic Social Affected The Result of Productivity Paddy Field Farming Management District Cianjur. Journal of scientific Faculty of Economic Management (JIMFE). 3(2): 37-48. Faculty of Economic UNB. Bogor.

Soekartawi. (2011). Farming Science. Indonesia University. Jakarta. 